Daniel Wicenty

https://orcid.org/0000-0003-0296-3882

Uniwersytet Gdański, Instytut Pamięci Narodowej Gdańsk

\title{
Świadek, uczestnik, ofiara. Wokół książki Wygnaniec. 21 scen z życia Zygmunta Baumana Artura Domosławskiego*
}

Zarys treści: Artykuł analizuje książkę Wygnaniec. 21 scen z życia Zygmunta Baumana Artura Domosławskiego przez pryzmat narracji historycznej (faktograficznej) oraz perspektyw problemowych, zaproponowanych przez Domosławskiego. W tym pierwszym aspekcie punktem odniesienia stały się przede wszystkim dwie inne wydane niedawno biografie Baumana autorstwa Dariusza Rosiaka i Izabeli Wagner. W tym drugim podjęty został głównie trop ofiary jako klucz do odczytania życia Baumana. Autor artykułu proponuje również rozważenie problemu intelektualnej oryginalności polskiego socjologa.

Abstract: The article analyses the book Wygnaniec. 21 scen $z$ życia Zygmunta Baumana (An Exile. 21 Scenes from the Life of Zygmunt Bauman) by Artur Domosławski through the prism of historical (factual) narration and problem perspectives proposed by Domosławski. In this first aspect, the main point of reference is made by two other recently published biographies of Zygmunt Bauman by Dariusz Rosiak and Izabela Wagner. The latter deals primarily with the metaphor of sacrifice as a key to reading Bauman's life. The author of the review article also proposes reflecting on the problem of the intellectual originality of the Polish sociologist.

Słowa kluczowe: Zygmunt Bauman, biografia, socjologia polska po $1945 \mathrm{r}$.

Keywords: Zygmunt Bauman, biography, Polish sociology after 1945

Artur Domosławski, doświadczony reporter, pisarz i biograf, w 2021 r. zaproponował czytelnikom biografię Zygmunta Baumana. Ponad 800 stron tekstu, obszerna i różnorodna bibliografia, przypisy, indeks nazwisk, dwie wkładki zdjęciowe oraz relacje zebrane od 72 osób robią więcej niż poważne wrażenie.

Podtytuł książki sugeruje strukturę złożoną z 21 części. Poniekąd tak jest. Tytułowe „sceny” porządkują narrację biograficzną, ułożoną w zasadzie

\footnotetext{
* A. Domosławski, Wygnaniec. 21 scen z życia Zygmunta Baumana, Wielka Litera, Warszawa 2021, ss. 906 .
} 
chronologicznie. $\mathrm{Z}$ układu tego wyłamuje się początek biografii, gdyż rozpoczyna ją „Scena dwudziesta (początek)”. „Sceny” poprzeplatane są „przystankami”. Te z kolei mają charakter bądź to odautorskiego komentarza, bądź to swoistej uwagi warsztatowej czy wreszcie pewnych miniatur reporterskich. Recenzję podzielę zatem zgodnie $\mathrm{z}$ tą podstawową strukturą książki na część opisową/historyczną oraz problemową.

Zacząć muszę od stwierdzenia, że bardziej szczegółowe omawianie tej zasadniczej, biograficznej części Wygnańca jest przedsięwzięciem nieco wtórnym. Dlaczego? Książka sprawia wrażenie pionierskiej, a lekko nieuważny czytelnik może odnieść po lekturze Wygnańca (mylne) wrażenie, że jest to pierwsza biografia Baumana. Domosławski nie jest jednak pierwszym, który podjął się napisania życiorysu znanego socjologa, a w książce znajdziemy zaledwie bardzo zdawkowe odniesienia do dwóch innych biografii Baumana: pióra Izabeli Wagner, wydanej w 2020 r. w języku angielskim (jej nazwiska nie ma w indeksie) ${ }^{1}$, oraz autorstwa Dariusza Rosiaka z 2019 r. ${ }^{2}$

Zacznijmy od biografii Wagner. Niewątpliwie Domosławski znał dokonania badaczki z Uniwersytetu Warszawskiego, gdyż raz odniósł się do nich w przypisie dolnym. Ich ścieżki badawcze pewnie nie raz musiały się przeciąć. Wagner rozpoczęła prace nad swoją książką w 2013 r., odwiedzając te same miejsca i rozmawiając z tymi samymi ludźmi co Domosławski. Oczywiście, nie ma powodu wytykać Domosławskiemu braku obfitych cytowań i odniesień do pracy wydanej rok wcześniej. Nie ma też powodu, aby ze względu na książkę Bauman. A biography dzieło Domosławskiego wyrzucić do kosza. Biografia Izabeli Wagner ma charakter stricte naukowy, a z racji tego, że została opublikowana po angielsku, przez angielskie (renomowane zresztą) wydawnictwo, krąg jej odbiorców oraz dostępność dla polskiego czytelnika są nieco inne. Ale - jeden przemycony przypis dolny sprawy nie załatwia, gdyż faktograficzne ustalenia, które moglibyśmy przyjąć jako autorskie ustalenia Domosławskiego, zostały już zaprezentowane w książce Wagner. Dzieciństwo, otoczenie rodzinne, wojenna tułaczka, służba w KBW, złożone relacje z Leszkiem Kołakowskim, dziwny okres pobytu w Izraelu itd., itp. - o tych wszystkich meandrach życia Baumana mogliśmy już u niej przeczytać. W książce Rosiaka i innych biograficznych pracach poświęconych Baumanowi zresztą po części też.

Oto dwa przykłady podające nieco w wątpliwość pracę Domosławskiego biografisty - a więc kogoś, wobec kogo zakładamy stworzenie możliwie szczegółowego opisu życia danej postaci oraz wniesienie wkładu poznawczego do wiedzy o niej. Ważnym odkryciem Autora Wygnańca wydaje się tu opowiadanie W Krzeczuchach znów spokój. Opowieść o żołnierzach KBW, które Bauman pod pseudonimem opublikował w wydawnictwie MON w 1953 r. Opowieść jest

\footnotetext{
${ }^{1}$ I. Wagner, Bauman. A biography, Cambridge 2020.

2 D. Rosiak, Bauman, Kraków 2019.
} 
schematyczna, propagandowa, choć utrzymana w ciekawym duchu „westernu socjalistycznego". Domosławski pisze, że na opowiadanie to zwrócił mu uwage Jerzy Wiatr (s. 174). Tymczasem pisała o nim wcześniej - i to dwukrotnie - Izabela Wagner (zarówno w biografii Bauman. A biography, jak i w artykule poświęconym pracy nad nią $\left.{ }^{3}\right)$. Nawiasem mówiąc, Wagner wykazała się przy tym większą dokładnością, wskazując na jeszcze jedno opowiadanie napisane przez Baumana pod pseudonimem (Na Kołobrzeg!).

Dzieciństwo i otoczenie rodzinne Baumana w Wygnańcu wydają się opisane w pogłębiony sposób. Jesteśmy sprawnie przeprowadzani przez zawiłości różnic statusów wśród polskich Żydów. Niejako mimochodem Domosławski zauważa ważkie światopoglądowe okoliczności rozwoju młodego Zygmunta - nie zainteresował się ani Talmudem, ani syjonizmem. Ideowym olśnieniem okazał się za to socjalizm jako skutek uboczny spotkań organizowanych przez Haszomer Hacair. Mamy także panoramę przedwojennego Poznania. Jest to obraz dość paradoksalny, bo w mieście silnie endeckim, z wyraźnym resentymentem antysemickim w przestrzeni publicznej, niemal nie było Żydów. Skąd zatem ów antysemityzm? Domosławski zadowala się tu pewnym fotograficznym opisem, głębszego kontekstu zaś skąpi (znajdziemy w Wygnańcu jeden krótki akapit na ten temat na s. 40). Zdecydowanie ciekawiej pod tym kątem wygląda analogiczny fragment w biografii autorstwa Dariusza Rosiaka. W książce Bauman (objętościowo trzykrotnie mniejszej!) znajdziemy zgrabnie i syntetycznie podane aspekty relacji polsko-żydowskich w Wielkopolsce w XIX w. na tle ówczesnej polityki niemieckiej oraz pragmatyczno-cywilizacyjnych wyborów Żydów na rzecz Rzeszy Niemieckiej

Z innych przemilczeń lub też przeoczeń bibliograficznych Autora Wygnańca niezrozumiały jest też dla mnie brak jakiejkolwiek wzmianki o artykule biograficznym Mateusza Burzyka i Michała Jędrzejka opublikowanym w 2018 r. w specjalnym numerze „Znaku” poświęconym Baumanowi ${ }^{5}$. Tekst ten jest obszernym, całościowym i ciekawym ujęciem życia Baumana, które śmiało mogłoby stanowić kościec dla chronologicznie ułożonej części biografii pióra Domosławskiego. Nawiasem mówiąc, dyskurs biograficzno-intelektualny wokół Zygmunta Baumana ma swoich wcale licznych przedstawicieli i Polsce, i za granicą ${ }^{6}$.

\footnotetext{
${ }^{3}$ I. Wagner, Zdjęcie z konkursu piękności i inne dokumenty osobiste. O pracy badawczej i poszukiwaniu znaczeń „czarnych dziur” - na przykładzie rekonstrukcji biografii Zygmunta Baumana, "Autobiografia” 2020, nr 1 (14), s. 152.

${ }^{4}$ D. Rosiak, op. cit., s. 11-30.

${ }^{5}$ M. Burzyk, M. Jędrzejek, Wszystkie życia Zygmunta Baumana, „Znak” 2018, nr 752 (całość dostępna na: https://www.miesiecznik.znak.com.pl/biografia-bauman-wszystkie-zycia-zygmuntabaumana/; dostęp: 21 VII 2021). Nawiasem biorąc, Domosławski nie odwołuje się też do innych artykułów zamieszczonych w tym numerze „Znaku”, ukazujących intelektualną odsłonę Baumana.

${ }^{6}$ Przy Uniwersytecie w Leeds istnieje The Bauman Institute, zajmujący się szeroko rozumianą teorią krytyczną oraz intelektualną spuścizną po Baumanie. Specjalne numery mu poświęcone wydały m.in. takie czasopisma jak „Polish Sociological Review” z 2006 r., „Theory, Culture \& Society”
} 
Jest w książce Domosławskiego nieco przestrzelonych interpretacji historycznych. Bodaj najistotniejsza dotyczy ujmowania walki powojennego aparatu bezpieczeństwa z podziemiem antykomunistycznym jako wojny domowej (s. 162-166). Domosławski nie dostrzega, że obok walczących stron dodatkowym superarbitrem była tu Armia Czerwona/Radziecka. W innym miejscu w polemicznym głosie o zaniedbaniach w badaniach nad doświadczeniami szeregowych żołnierzy 1. i 2. Armii Wojska Polskiego (słusznie podniesionym) interpretuje pomniki wdzięczności Armii Radzieckiej w perspektywie walki z Trzecią Rzeszą (s. 128). Niektóre tezy rysuje bez jakiegokolwiek konkretu empirycznego i ze z góry przyjętą (zupełnie niezasadną) tezą. Odnośnie do obrazu tużpowojennej Polski znajdziemy taki fragment: „Innym szalejącym zabójcą jest zemsta: Polacy nienawidzą Niemców i jeśli któryś z nich wpada im w ręce, przeważnie ginie" (s. 139) ${ }^{7}$.

Na szczęście Wygnaniec nie jest hagiografią. Domosławski nie próbował być wobec żadnego okresu życia Baumana wybiórczy i jest uczciwy w tym względzie, że roztrząsa wszystkie kontrowersyjne elementy biografii. Autor Wygnańca dokumentuje także różne słabostki Baumana lub też te jego cechy, które trudno wkomponować w obraz intelektualnego guru lewicy. Myśliciel okazuje się być dość krytyczny wobec nurtów spod znaku gender studies. Jest także domowym patriarchą, ze skłonnościami do kontrolowania swojego najbliższego otoczenia, w tym żony i gości, których potrafi zamęczyć przygotowanym przez siebie obiadem. Niemniej jednak Domosławski konsekwentnie broni swojego bohatera, tłumaczy go, racjonalizuje jego działania. Autor Wygnańca jest zatem przede wszystkim biografem-adwokatem, bardzo rzadko i co najwyżej subtelnie wchodząc $\mathrm{w}$ rolę demaskatora.

Spójrzmy na drugi, interpretacyjny wymiar Wygnańca. Domosławski proponuje nam opowieść o Baumanie, który „chciał przetrwać w ludzkiej pamięci jako myśliciel, humanista, socjolog, a nie major KBW - postać z czarnej legendy" (s. 21). To napięcie dotyczące pamięci o Baumanie towarzyszy całej książce, a nawet więcej - w gruncie rzeczy stanowi oś całości. Na wstępie Autor apeluje o uczciwość wobec swojego bohatera, a także deklaruje własną uczciwość wobec jego życiorysu: „Możliwe, że Bauman podejmował decyzje i dopuszczał się czynów, które zasługują na krytyczną ocenę, niechęć, nawet potępienie. Trzeba jednak je ustalić, dowieść ich, ukazać je w pełnym kontekście historii. Tymczasem cały publiczny «proces» Baumana, jaki na raty prowadzono przez lata [...] był niesprawiedliwy i nieuczciwy" (s. 23). Od problemu czarnej legendy książka się zaczyna i w pewnym sensie na nim się kończy. Zatem nie dziwi, że klucz,

w 2018 r. oraz miesięcznik „Znak” w 2018 r. Jest co najmniej kilkoro badaczy zajmujących się systematycznie życiem i dorobkiem Baumana (zob. także bibliografia w książce Rosiaka, s. 243).

${ }^{7}$ Pogłębione i wyważone studium dotyczące problemu (braku) zemsty Polaków na Niemcach proponuje Lech Nijakowski, Rozkosz zemsty. Socjologia historyczna mobilizacji ludobójczej, Warszawa 2014. 
jaki do odczytania Zygmunta Baumana proponuje Domosławski, krąży wokół kategorii osobności, outsidera czy tytułowego wygnańca. Bauman osadzony jest konsekwentnie w roli obcego, bezdomnego i ofiary.

Figura ofiary jest dla Domosławskiego bodaj najważniejsza. Jest to poniekąd zrozumiałe ze względu na ideowe (lewicowe) powinowactwo Autora, od którego on sam w żadnym razie się nie odżegnuje. Widzimy więc Baumana - ofiarę systemów, stereotypów, ideologii czy wreszcie niesprawiedliwości dziejowych. Ja jednak widzę w tym wyborze klucza parę problemów.

Pierwszy to pewna niespójność odbioru. Emocjonalne zaangażowanie, jakie chce wywołać Domosławski u czytelników, ze względu na kategorię ofiary koncentruje się wokół litości. A jednocześnie Autor Wygnańca pragnie dla Baumana podziwu, sam go zresztą podziwia. $\mathrm{W}$ porządku emocjonalnym podziw niespecjalnie idzie w parze z litością. Co więcej, Bauman, tak jak go rysuje Domosławski, pragnął być raczej podziwiany niż traktowany z litością. Był dumny, ambitny, świadom własnej wartości i sławy, i gotów mocować się z rzeczywistością (czego świetnym znakiem było nauczenie się języka hebrajskiego podczas pierwszych miesięcy pobytu w Izraelu). Niespójność ta przebija się także w tytułach poszczególnych rozdziałów („Głodny Zygmunt”, „Poraniony wygnaniec”, „Polowanie na Baumana”, ale też „Prorok, socjolog, opiekun”, „Nasz sławny rodak z Zachodu”).

Sprawa kolejna - rola Baumana ofiary jest miejscami przez Domosławskiego wyolbrzymiana. Wygnaniec sprawia wrażenie, że los bohatera jest typiczno-idealnym przykładem ofiary Żyda, rewizjonisty, intelektualisty niegodzącego się na niegodziwości tego świata. Tymczasem intelektualistów wygnańców było w PRL więcej. Co ważne, pewna (większa?) część z nich doświadczyła dramatycznych zwrotów życiowych z powodu innych względów niż Bauman. Los polskich wygnańców socjologów Bauman dzielił z Florianem Znanieckim, Adamem Podgóreckim, Aleksandrem Matejką i Marią Łoś, by wymienić tylko kilkoro. Z Leszkiem Kołakowskim zresztą także, ale życie Kołakowskiego w Wygnańcu stanowi raczej kontrapunkt wobec życia Baumana niż wspólny z nim mianownik.

Zgodzę się z Autorem, że w niektórych dyskusjach dotyczących powojennej Polski Bauman bywał nie do końca słusznie obsadzany w roli kozła ofiarnego oraz ucieleśnienia zła stalinizmu. Ale jednocześnie Domosławski popada w przesadę, pisząc: „Myślę, że Bauman oberwał za wszystkich i za wszystko. Za stalinizm. Za Polskę Ludową. Za cały realny socjalizm. Za to, co robił, i za to, czego nie robił. Za to, co pisał, i za to, czego nie napisał. Za tych, którym osobiście zalazł za skórę, i za tych, których zalewa żółć z powodu sukcesów, jakie odniósł na świecie" (s. 787). Nie był zresztą Bauman wobec tego przypominania stalinowskiej przeszłości tak stoicki, jak się to rysuje w Wygnańcu. W biografii Rosiaka przeczytamy o obsesyjnym czytaniu opinii na swój temat (zwłaszcza z portali prawicowych) ${ }^{8}$.

\footnotetext{
${ }^{8}$ D. Rosiak, op. cit., s. 194, 221.
} 
Zatem, nieco natrętnie przypominany przez Domosławskiego trop ofiary jako klucz do życia Baumana nie jest zabiegiem nadzwyczaj trafnym. Pojemniejsza wydaje się tu formuła zaproponowana we wspomnianym tekście Burzyka i Jędrzejka: „Cała trudność leży w tym, by zaakceptować fakt, że autor Płynnej nowoczesności odegrał w tej historii różne role: był jej świadkiem, uczestnikiem i ofiarą"9.

Jeden z krytycznych momentów życia Baumana wiązał się z odkryciem Związku Patriotów Polskich („upajał się” treściami z czasopism ZPP, s. 93). W konsekwencji doprowadziło go to do zaciągnięcia się do tworzonego w ZSRR Wojska Polskiego (4. Dywizja Piechoty). Jak jednak traktować wejście do KBW (Bauman został oficerem polityczno-wychowawczym)? Jest tu przecież jakaś zagadka, nieoczywistość. Domosławski podaje tu tezę o uwiedzeniu ${ }^{10}$, a obok mówi też o świadomym wyborze, którego Bauman nigdy się nie wyparł. Ostatecznie czytelnik pozostanie z wyznaniem bohatera, że „innego życia nie mógł mieć”. Poczucie pewnej niejasności pogłębia tylko teza o powojennej wojnie domowej, służąca Domosławskiemu jako element zrozumienia (usprawiedliwienia?) akcesu Baumana do KBW.

Także problem podwójnej tożsamości polsko-żydowskiej przynosi w Wygnańcu pewne rozczarowanie. Rozdział „Żydowski Polak, polski Żyd” znów nachalnie przypomina figurę ofiary - tym razem ofiarę ciasnych przekonań etnicznie kształtowanej wspólnoty (Polaków), która wytwarza "mentalność oblężonej twierdzy” oraz bywa zdjęta "paranoicznym strachem” przed nie swoimi (s. 61). Z kolei wybór roli „obcego" i „nieprzynależącego” (integralnej zresztą z „płynnością świata”), tłumaczony jako kulturowe żydowskie powinowactwo (s. 466), omija fenomen Żydów zasymilowanych. Znacznie ciekawej o podwójnej tożsamości Baumana pisze Izabela Wagner, wychodząc od interakcjonistycznego (sytuacyjnego) ujęcia tożsamości i zwracając uwagę na powracający w życiu Baumana problem „czarnych dziur", czyli przemilczanych elementów biografii ${ }^{11}$.

Domosławski stawia Baumana w pierwszej lidze światowych myślicieli. Słabo jednak tłumaczy jego wielkość. Wypada zauważyć przy tym, że objętość Wygnańca jest jak najbardziej stosowna, aby wywiązać się z tego zadania. W zasadzie odniesienia do intelektualnej spuścizny Baumana są prostymi omówieniami, dość bezkrytycznymi, obfitującymi za to w określenia w rodzaju „proroczy”, „przenikliwy”. Książka zaczyna się od przypomnienia wspólnej debaty z Samuelem Huntingtonem i Benjaminem Barberem w 2004 r. Domosławski wraca do tej sytuacji pod koniec książki: „Jako trzeci głos zabiera Bauman. Błyszczy na tle niemrawego

${ }_{9}$ M. Burzyk, M. Jędrzejek, op. cit.

${ }^{10}$ Rosiak poszedł tym samym tropem, pisząc o „ukąszeniu”. Jeśli ktoś się nie zadowoli tymi poniekąd wyświechtanymi kliszami interpretacyjnymi, może sięgnąć po klasyczną, niedawno wydaną po polsku książkę Jaffa Schatza Pokolenie, w tym fragment poświęcony relacjom między marksizmem a żydowskim radykalizmem (J. Schatz, Pokolenie. Wzlot i upadek polskich Żydów i komunistów, tłum. S. Kowalski, Warszawa 2020).

11 I. Wagner, Zdjęcie z konkursu piękności..., s. 152-160. 
i bezbarwnego Huntingtona. Barber, który w czasie wystąpienia amerykańskiego kolegi przysypia, nagle budzi się, gdy dociera do niego donośny, żywy głos Baumana, a po chwili docierają do niego myśli" (s. 709). To ładny, sugestywny opis, ale w zasadzie pozbawiony konkretnych argumentów. Odrzucając podobne opinie Domosławskiego oraz przytaczane przez niego wypowiedzi, takich argumentów w gruncie rzeczy w książce nie znajdziemy.

Podążę chwilę tym tropem. Proste ilościowe kryteria wskazują na Baumana jako na jedną z bardziej znaczących postaci światowej socjologii ${ }^{12}$. Ma też on swój oryginalny wkład koncepcyjny i pojęciowy do słownika socjologii/humanistyki. Metafory i pojęcia, którym dał życie, krążą z powodzeniem w dyskursie naukowym i publicystycznym od kilkudziesięciu lat. Stopień upowszechnienia niektórych jest tak duży (vide „płynność”), że ta część spuścizny Baumana balansuje na krawędzi intelektualnej powagi i frazesu ${ }^{13}$. Ponadto, jak pokazuje Tomasz Kunz, tłumacz Baumana, jego instrumentarium pojęciowe nie jest przesadnie rozbudowane i bazuje na przejrzystym schemacie opozycji. Język jego książek jest potoczysty i zrozumiały (po polsku brzmiący nieco gorzej) ${ }^{14}$. Teza Baumana o związku nowoczesności z zagładą Żydów jest żywa wśród historyków badających II wojnę światową. Dodajmy jeszcze niezwykłą płodność Baumana, a także fakt last but not least - że pewnie żadna z jego książek objętościowo nie przekroczyła 300 stron (a niemało z nich ma mniej niż 200).

Recepcja w polskiej socjologii akademickiej jest rzeczą bardziej skomplikowaną. Są tu zaszłości środowiskowe (krąg Hochfelda vs. krąg Ossowskich; Domosławski zgrabnie to opisuje), ale też kwestia rozjeżdżających się perspektyw polskiej i baumanowskiej socjologii, zwłaszcza w latach dziewięćdziesiątych ubiegłego wieku (polski mainstream socjologiczny był zaangażowany w legitymizację liberalnego społeczeństwa i ładu gospodarczego, a Bauman był surowym krytykiem kapitalizmu i reformy Leszka Balcerowicza) ${ }^{15}$. Jednocześnie pewną trwałość myśli

12 Poprzez bazę JSTOR zliczyłem 113 naukowych recenzji książek Baumana, wydrukowanych w czasopismach anglojęzycznych. Zapewne drugie tyle recenzji znaleźlibyśmy w czasopismach hiszpańskojęzycznych, o innych językach nie wspominając. Analogiczne kryteria wskazują na 197 recenzji książek Anthony’ego Giddensa. Sądzę, że w uniwersum polskich socjologów Bauman jest w tym względzie na samym szczycie. Dwie porównywalne postacie, jedna historyczna i jedna współczesna - Florian Znaniecki i Piotr Sztompka - wedle przyjętych tu kryteriów osiągnęli wyniki odpowiednio 57 i 34 recenzje.

13 Zob. E. Illouz, Oceniał rzeczy trafnie, ale za mało empirycznie, „Znak” 2018, nr 752, http://www. miesiecznik.znak.com.pl/swiat-porozniony-albo-maly-slownik-baumanowskich-opozycji/ (dostęp: 21 VII 2021).

14 T. Kunz, Świat poróżniony albo mały słownik Baumanowskich opozycji, „Znak” 2018, nr 752, http://www.miesiecznik.znak.com.pl/swiat-porozniony-albo-maly-slownik-baumanowskichopozycji/ (dostęp: 21 VII 2021).

15 Zob. Anioł historii boi się o przyszłość, zapis fragmentu dyskusji Dariusza Brzezińskiego, Macieja Gduli, Tomasza Majewskiego, Joanny Tokarskiej-Bakir i Marty Duch-Dyngosz, „Znak” 
Baumana zapewniają podręczniki do socjologii. Omówienia poszczególnych koncepcji Baumana znajdują się w dwóch bodaj najlepszych polskich podręcznikach pióra Barbary Szackiej i Piotra Sztompki ${ }^{16}$.

Co tu jest wielkością, a co sławą? Ta ostatnia jest niepodważalna. O tej pierwszej Domosławski nie przekonuje.

Znajduję też w książce jeszcze jeden drobny kiks ze strony Autora. Otóż obszerne fragmenty z rozdziału „Scena pierwsza” mają charakter autoplagiatu. Jest on w poszczególnych fragmentach niemal kopią wcześniejszego artykułu Domosławskiego Zygmunt Bauman - życie w oparach antysemityzmu, opublikowanego w „Polityce” w grudniu 2018 r. ${ }^{17}$ Artykułu tego Domosławski nie wymienił w bibliografii.

Książka nie jest dla czytelnika, który preferuje biografa przezroczystego, niezaangażowanego emocjonalnie, pozytywizującego. Elementów, w których Domosławski jest na pierwszym planie, jest w książce niemało i wynika to nie tylko z przyjęcia dla części książki (rozdziały-przystanki) konwencji quasi-reportażu. Autor, zwłaszcza na końcu, staje się także publicystą bieżącej sytuacji politycznej w Polsce (np. uwaga o „rządach bezprawia i niesprawiedliwości”, s. 839). Nie jest też dla czytelników, którzy preferują model uczonego-badacza, nie zaś aforysty, filozofa społecznego, swoistego połączenia guru $\mathrm{z}$ ideologiem. Bauman nie jest badaczem, nigdy nim nie był, nigdy nim nie chciał być. Jasno wykłada to w swoim tekście Pro domo sua ${ }^{18}$.

Wygnaniec pozostawia pytanie o zasadność trzeciej (!) biografii Baumana wydanej na przestrzeni trzech lat bez jednoznacznej odpowiedzi. Starania Domosławskiego biografisty wobec wcześniejszych biografii Wagner i Rosiaka wydają się cokolwiek drugorzędne. Nawiasem biorąc, przetłumaczona książka Wagner lada moment pojawi się na naszym rynku wydawniczym (recenzję piszę w lipcu 2021 r.).

2018, nr 752, http://www.miesiecznik.znak.com.pl/aniol-historii-boi-sie-o-przyszlosc-dyskusjazygmunt-bauman/ (dostęp: 21 VII 2021).

16 Zob. B. Szacka, Wprowadzenie do socjologii, Warszawa 2003; P. Sztompka, Socjologia. Analiza społeczeństwa, Kraków 2002.

17 Zob. https://www.polityka.pl/tygodnikpolityka/historia/1775434,1,zygmunt-bauman--zycie-woparach-antysemityzmu.read (dostęp: 14 VII 2021).

18 Z. Bauman, Pro domo sua. Bauman o Baumanie, tłum. T. Kunz, „Znak” 2018, nr 752, http:// www.miesiecznik.znak.com.pl/pro-domo-sua-bauman-o-baumanie/ (dostęp: 22 VII 2021). Swoją drogą, podejście to dobrze odczytywać w perspektywie wyzwań współczesnej socjologii (zob. K. Pietrowicz, Pomiędzy data science a performansem. O niektórych wyzwaniach stojacych przed wspótczesną socjologią, „Ruch Prawniczy, Ekonomiczny i Socjologiczny” 2020, z. 4, s. 335-346). 


\section{Witness, Participant, Victim. Around the book An Exile. 21 Scenes from the Life of Zygmunt Bauman by Artur Domosławski (Summary)}

The article analyses the book Wygnaniec. 21 scen z życia Zygmunta Baumana (An Exile. 21 Scenes from the Life of Zygmunt Bauman) by Artur Domosławski. Following the logic of the book's structure adopted by Domosławski (the chapters are divided into 'scenes' and 'stops'), the biography is discussed through the prism of historical (factual) narration and problem fields recognised by Domosławski as crucial for reading and interpreting Bauman's life. In this first context, the article assesses Domosławski as a biographer, and therefore mainly as a historian-researcher, using two other recently published biographies of Zygmunt Bauman - by Dariusz Rosiak (Bauman, published in 2019) and by Izabela Wagner (Bauman. A Biography, published in 2020). The review's author formulates some specific critical remarks here. In the second context, he discusses the metaphors and categories proposed as tools for interpreting Bauman's life. Above all, he assesses the metaphor of the victim, recognising it as inappropriate and unjustified in relation to some vital aspects of the Polish sociologist's life. In the last part of the review article, its author proposes reflecting on the intellectual originality of Zygmunt Bauman's concepts.

\section{Bibliografia}

Anioł historii boi się o przyszłość, zapis fragmentu dyskusji Dariusza Brzezińskiego, Macieja Gduli, Tomasza Majewskiego, Joanny Tokarskiej-Bakir i Marty Duch-Dyngosz, „Znak” 2018, nr 752, http://www.miesiecznik.znak.com.pl/aniol-historii-boi-sie-o-przyszlosc-dyskusja-zygmuntbauman/ (dostęp: 21 VII 2021)

Bauman Z., Pro domo sua. Bauman o Baumanie, tłum. T. Kunz, „Znak” 2018, nr 752, http://www. miesiecznik.znak.com.pl/pro-domo-sua-bauman-o-baumanie/ (dostęp: 22 VII 2021)

Burzyk M., Jędrzejek M., Wszystkie życia Zygmunta Baumana, „Znak” 2018, nr 752, https:// www.miesiecznik.znak.com.pl/biografia-bauman-wszystkie-zycia-zygmunta-baumana/ (dostęp: 21 VII 2021)

Domosławski A., Wygnaniec. 21 scen z życia Zygmunta Baumana, Warszawa 2021

https://www.polityka.pl/tygodnikpolityka/historia/1775434,1,zygmunt-bauman--zycie-w-oparachantysemityzmu.read (dostęp: 14 VII 2021)

Illouz E., Oceniał rzeczy trafnie, ale za mało empirycznie, „Znak” 2018, nr 752, http://www.miesiecznik.znak.com.pl/swiat-porozniony-albo-maly-slownik-baumanowskich-opozycji/ (dostęp: 21 VII 2021)

Kunz T., Świat poróżniony albo mały słownik Baumanowskich opozycji, „Znak” 2018, nr 752, http://www.miesiecznik.znak.com.pl/swiat-porozniony-albo-maly-slownik-baumanowskichopozycji/ (dostęp: 21 VII 2021)

Nijakowski L., Rozkosz zemsty. Socjologia historyczna mobilizacji ludobójczej, Warszawa 2014

Pietrowicz K., Pomiędzy data science a performansem. O niektórych wyzwaniach stojących przed wspótczesna socjologią, „Ruch Prawniczy, Ekonomiczny i Socjologiczny” 2020, z. 4, s. 335-346

Rosiak D., Bauman, Kraków 2019

Schatz J., Pokolenie. Wzlot $i$ upadek polskich Żydów i komunistów, tłum. S. Kowalski, Warszawa 2020

Szacka B., Wprowadzenie do socjologii, Warszawa 2003

Sztompka P., Socjologia. Analiza społeczeństwa, Kraków 2002

Wagner I., Bauman. A biography, Cambridge 2020 
Wagner I., Zdjęcie z konkursu piękności i inne dokumenty osobiste. O pracy badawczej i poszukiwaniu znaczeń „czarnych dziur” - na przykładzie rekonstrukcji biografii Zygmunta Baumana, „Autobiografia" 2020, nr 1 (14), s. 152

Daniel Wicenty (ur. 1977), dr hab. nauk humanistycznych, socjolog. Pracownik Oddziałowego Biura Badań Historycznych IPN w Gdańsku, profesor w Instytucie Socjologii Uniwersytetu Gdańskiego. Badacz środowisk socjologicznych i dziennikarskich w PRL, Służby Bezpieczeństwa oraz pamięci społecznej o PRL. Autor lub współautor książek: Zagubiona rzeczywistość. O społecznym konstruowaniu niewiedzy (Warszawa 2005, wspólnie z R. Sojakiem), Załamanie na froncie ideologicznym. Stowarzyszenie Dziennikarzy Polskich od Sierpnia '80 do stanu wojennego (Gdańsk 2012), Weryfikacja gdańskich dziennikarzy w stanie wojennym (Gdańsk 2015), Zgniłe jabłka, zepsute skrzynki i złe powietrze. Dysfunkcje w Stużbie Bezpieczeństwa w latach siedemdziesiatych i osiemdziesiątych XX wieku (Gdańsk-Warszawa 2018); współredaktor tomu Brudne wspólnoty. Przestępczość zorganizowana $w$ PRL $w$ latach siedemdziesiątych i osiemdziesiatych XX wieku (Gdańsk-Warszawa 2018, wspólnie z K. Nawrockim).

Kontakt: daniel.wicenty@ipn.gov.pl 